\title{
ПСИХОЛОГІЧНІ АСПЕКТИ МОВНОЇ ГРИ ЯК ЗАСОБУ ВПЛИВУ НА СВІДОМІСТЬ ЛЮДИНИ
}

\section{Хайрулін Олег}

Національний університет оборони України імені Івана Черняховського, м. Київ, Україна, oleg.khairulin.ph@gmail.com

Мета. Посилення ігрових, маніпулятивних аспектів сучасного комунікативного середовища, усього комплексу його впливів на особистість $\mathrm{i}$ соціальні процеси, актуалізує шерег ризиків і загроз, що пов'язані з можливим використанням інформаційного (медіа) простору для дестабілізації соціального благополуччя українського суспільства. Сучасні медіа-засоби і технології їх застосування дозволяють використовувати психологічні закономірності впливу інформації на свідомість, ціннісну, психоемоційну сфери та поведінку людини, наносити збиток іiі психологічному добробуту та безпеці. Тому наведене дослідження має на меті теоретично дослідити психологічні закономірності феномену мовної (мовленнєвої) гри як засобу впливу на свідомість людини, обгрунтувати семантико-психологічну детермінацію наслідків такого впливу.

Методи. У дослідженні застосовано методи абдукції, феноменологічної редукції, метод аналізу і систематизації наукових положень та підходів до вивчення психологічних закономірностей феномену мовної (мовленнєвої) гри, метод теоретичної реконструкції (моделювання) семантико-психологічної детермінації впливу інформаційних засобів на свідомість людини.

Результати. За результатами дослідження конкретизовано категоріальнопонятійний зміст психологічних аспектів феномену мовної (мовленнєвої) гри у контексті використання ऑï ефектів для впливу на психічну сферу людини. Актуалізовано атрибутивність наведених аспектів у процесах, що пов'язані 3 проблематикою інформаційно-психологічної безпеки особистості в сучасних умовах. Обгрунтовано семантико-психологічну детермінацію наслідків впливу інформаційних засобів, медіа на свідомість людини. Поглиблено наукові уявлення про характер впливу масової комунікації на психічну сферу людини через психологічні ефекти ігрової дії вербальної інформації. Встановлено, що психогенні ефекти медіа-впливу пов'язані передусім із перформативним характером інформаційних повідомлень та особливостями семантикосинтаксичної організації тексту. Наведені аспекти через механізми психічного системогенезу діють як пускові аферентації для мотиваційної активізації психіки адресата, його сприйняття та засвоєння інформації адресанта. Такі перформативні та семантико-синтаксичні властивості тексту представлені у

ISSN 2308-3743 (Online), ISSN 2227-1376 (Print)

(C) Хайрулін О., 2021. Ця стаття відкритого доступу на умовах CC BY-NC 4.0 
ньому лексемами-носіями ефектів активного навіювання.

Висновки. Результати дослідження дозволяють висновки про актуальність продовження психологічних та психолінгвістичних розвідок феномену мовної (мовленнєвої) гри як джерела i засобу маніпулятивного, індоктринального впливу на свідомість людини, а також про доцільність врахування психологічних особливостей явища мовної (мовленнєвої) гри в аналізі медіаконтенту, виявленні джерел інформаційно-психологічного (перформативного) впливу інформації на свідомість адресата та прогнозуванні наслідків такого впливу на особистість і соціальні процеси.

Ключові слова: медіа, гра, свідомість, текст, мовна гра, перформативність, інформаційно-психологічна безпека особистості, психологічний аналіз.

\section{Khairulin Oleg. Psychological Aspects of Language Game as to Mean of Influence on Human Consciousness.}

Purpose. Strengthening of game and manipulative aspects of modern communicative environment actualizes risks and threats which are related to the possible use of informative (medias) space for destabilization of social prosperity of Ukrainian society. Modern medias-facilities and technologies of their application allow to use psychological conformities to law of influence of information on human consciousness and behavior, to inflict the loss of human psychological welfare and safety. Therefore the brought research over has for an objective in theory to investigate psychological conformities to law of the phenomenon of language (talking) game as to the mean of influence on human consciousness, to ground semantic-psychological determination of consequences of such influence.

Methods. The methods of abduction, phenomenological reduction are applied in research. Also used method of analysis and systematization of scientific positions and going near the study of psychological conformities to law of the phenomenon of language (talking) game, method of theoretical reconstruction (modeling) of semantic-psychological determination from influence of informative facilities on human consciousness.

Results. On results research category-concept maintenance of psychological aspects of the phenomenon of language (talking) game is specified in the context of the use of her effects for influence on the psychical human sphere. The attributiveness the brought aspects over actualizes in processes which are related to problems of informatively-psychological safety of personality in modern terms. Semantic-psychological determination of consequences of influence of informative facilities, medias is reasonable on human consciousness. Scientific ideas are deep about character of influence of mass communication on the psychical sphere of man through the psychological effects of playing action of verbal information. It is set that the psychogenic effects of mediainfluence are related foremost to performative character of information messages and features of semantic-syntactic organization of text. The brought aspects over through the mechanisms of psychical system-genesis operate as stimulant for motivational activation of psyche of addressee, his perception 
and mastering of information of sender. Such performative and semantic-syntactic properties of text are presented in him by the lexemes-transmitters of effects of active suggestion.

Conclusions. Research results allow conclusions about actuality of continuation of psychological and psycholinguistic secret services of the phenomenon of language (talking) game as a source and mean manipulative, indoctrinal influence on human consciousness and also about expedience of account of psychological features of the phenomenon of language (talking) game in the analysis of mediacontent, exposure of sources of informatively-psychological (performative) influence of information on consciousness of addressee and prognostication of consequences of such influence on personality and social processes.

Keywords: medias, game, consciousness, text, language game, performativity, informatively-psychological safety of personality, psychological analysis.

\section{Хайрулин Олег. Психологические аспекты языковой игры как средства воздействия на сознание человека.}

Цель. Усиление игровых, манипулятивных аспектов современной коммуникативной среды актуализирует риски и угрозы, которые связаны с возможным использованием медиа для дестабилизации социального благополучия украинского общества. Современные медиа-средства и технологии их приложения позволяют использовать психологические закономерности влияния информации на сознание и поведение человека, наносить ущерб его психологическому благосостоянию и безопасности. Поэтому приведенное исследование имеет целью теоретически исследовать психологические закономерности феномена языковой (речевой) игры как средства влияния на сознание человека, обосновать семантикопсихологический детерминизм последствий такого влияния.

Методы. В исследовании применены методы абдукции, феноменологической редукции, метод анализа и систематизации научных положений и подходов к изучению психологических закономерностей феномена языковой (речевой) игры, метод теоретической реконструкции (моделирование) семантико-психологического детерминизма влияния информационных средств на сознание человека.

Результатами исследования конкретизировано категориально-понятийное содержание психологических аспектов феномена языковой (речевой) игры в контексте использования ее эффектов для влияния на психическую сферу человека. Актуализирована атрибутивность приведенных аспектов в процессах, которые связаны с проблематикой информационно-психологической безопасности личности в современных условиях. Обоснован семантикопсихологический детерминизм последствий влияния медиа на сознание человека. Углублены научные представления о характере влияния массовой коммуникации на психическую сферу человека посредством психологических эффектов игрового действия вербальной информации. Установлено, что психогенные эффекты медиа-влияния связаны прежде всего с перформативным 
характером информационных сообщений и особенностями семантикосинтаксической организации текста. Приведенные аспекты через механизмы психического системогенеза действуют как аферентации для мотивационной активизации психики адресата, его восприятия и усвоения информации адресанта. Такие перформативные и семантико-синтаксические свойства текста представлены в нем лексемами-носителями эффектов активного внушения.

Выводы. Результаты исследования позволяют выводы об актуальности продолжения психологических и психолингвистических исследований феномена языковой (речевой) игры как источника и средства манипулятивного, индоктринального влияния на сознание человека, а также о целесообразности учета психологических особенностей языковой (речевой) игры в анализе медиаконтента, выявлении источников информационно-психологического (перформативного) влияния информации на сознание адресата и прогнозировании последствий такого влияния на личность и социальные процессы.

Ключевые слова: медиа, игра, сознание, текст, языковая игра, перформативность, информационно-психологическая безопасность личности, психологический анализ.

Вступ. Сучасні умови життєдіяльності людини і суспільства характеризуються невпинним та поступовим накопиченням ознак критичної невизначеності, дефіциту передбачуваності, раціональних засновків для продуктивного прийняття рішень та соціальної взаємодії. Такі умови стали одним із засобів так званої гібридної або асиметричної війни. На сьогодні засоби гібридної війни активно використовуються суб’єктами геополітичного протистояння, зокрема керівництвом Російської Федерації. Геополітична стратегія цієї країни передбачає досягнення військово-політичних цілей, зокрема й через використання інформаційного (медіа) простору. На теренах Російської Федерації активно поширюються наукові дискурси геймифікації (іграїзації) та дотичного до ігрової тематики рефлексивного управління. У більшості ігровий, маніпулятивний характер сучасного глобального комунікативного середовища, усього комплексу його впливів на особистість і соціум підкреслюється висновками самих російських дослідників (Кара-Мурза, 2000; Новиков, Чхартишвили, 2003; Смолян, 2013; Навасартян, 2017).

Представники російської психологічної школи зауважують (О .К. Тихомиров та ін.): «життя показало, що дослідження ігрової діяльності, яка реалізується в новому інформаційному середовищі, може вважатися одним із найбільш актуальних завдань» 
(Войскунский спіавт., 2009: 85).

За наведених обставин, що уможливлюють реальні загрози добробуту i соціальній стабільності українського суспільства, вітчизняна психологія повинна своєчасно і якісно робити свій внесок у справу стримування й усунення соціальних наслідків від комунікативної активності зовнішніх недружніх сил, використання інформаційного (медіа) простору для дестабілізації соціального благополуччя українського суспільства.

Грунтовна розробка ключових аспектів проблематики психогенного впливу інформації на людину відображена в працях психологів та представників психолінгвістичного напряму Л. С. Виготського, Л. Вітгенштайна, Д. Остіна, Т. М. Титаренко, Л.В.Засєкіної, Л. А. Найдьонової, С. Г. Денисюк, О.М.Кочубейник, Л. Ф. Компанцевої, Н. А. Агаєва, В. В. Зірки, К. О. Черемних, I. В. Александрук, О. О. Золотар, О. О. Селіванової, Д. Мак-Квейла, Д. Лакоффа, М. Джонсона та ін.

На ігрову природу комунікації і діяльності людини у ній вказує чисельна кількість досліджень широкого наукового, хронологічного $\mathrm{i}$ змістовного діапазону. Відповідно до них гра - це: засіб наслідування діяльності, навчання (Платон); джерело душевної рівноваги, гармонії душі й тіла, спосіб відпочинку і психічної розрядки (Аристотель, М. Лацарус); творче начало, що породжує світ культури (Ф. Шиллер, Й. Гейзінга); первинна форма залучення людини до соціуму (К. Гросс); атрибут культури і форма соціальної реалізації людиною власних прагнень, потягів (Р. Кайуа); соціальна умова буття (П. Бурд’є); активність, що формує фантазію, уяву, інтелект (Ф. Бейтендейк); різновид індивідуальної і колективної поведінки (К. Рейнуотер); форма творчості з певною метою (Ж. Піаже); спосіб самореалізації індивіда, структура його поведінки, основа комунікації та міжособистісного спілкування (Е. Берн); преадаптивна неутилітарна поведінка (О. Асмолов); модель комунікації або конституції тексту, в якій відтворюється несуперечливий контекст і слова вживаються у суворо визначеному сенсі (Л. Вітгенштайн) тощо.

Гра як модус діяльності атрибутивно передбачає інтеракцію (взаємодію), спілкування, комунікацію. Позбавлена циклічності, репродуктивного повторення, така, що має хоча б мізерну долю невизначеності, комунікація і є грою. Тобто комунікація у більшості гра. 
Аналіз актуальних розвідок щодо виконання завдань дослідження засвідчує, що переважні дискурси та проведені дослідження поступово зосереджуються в контурі з центром, який постає у вигляді феномену гри (Гейзинга, 1938; Вітгенштайн, 1958; Остін, 1964; Фурман, Шандрук, 2014). Методологічною та предметною платформою тут виступає теорія мовних (мовленнєвих) ігор Л. Вітгенштайна та концепція мовних актів і перформативності тексту Д. Остіна.

У національному науковому полі дослідження ігрової сутності комунікативних процесів представлено, зокрема, розвідкою С. Г. Денисюк, якою запропоновано здійснювати моделювання таких процесів з урахуванням психологічних закономірностей спілкування і масової комунікації на основі здобутків теорії ігор (Денисюк, 2015).

Мета статті полягає у спробі засобами наукової рефлексії здійснити теоретичне дослідження психологічних закономірностей феномену мовної (мовленнєвої) гри як засобу впливу на свідомість людини та атрибуту інформаційно-психологічної безпеки особистості в сучасних умовах, обгрунтувати семантико-психологічну детермінацію наслідків впливу інформаційних засобів, медіа на свідомість людини.

Методи та процедура дослідження. Стаття має характер теоретико-методологічної розвідки, тому основними методами дослідження $є$ метод абдукції, феноменологічний метод, аналіз і систематизація наукових положень та підходів до вивчення психологічних закономірностей феномену мовної (мовленнєвої) гри як засобу впливу на свідомість людини, теоретична реконструкція (моделювання) семантико-психологічної детермінації впливу інформаційних засобів на людину.

Базовим атрибутом нашого дослідницького дискурсу, що визначає його змістовну сутність, є феномен тексту (від лат. textum сплетіння, побудова, зв'язок) - знаково-мовної реалізації певної системи інформації та аспекти семантико-психологічного впливу інформації (тексту) на особистість людини. Українська дослідниця I. В. Александрук висновує, що кожен текст розглядається людиною як світ, а світ - як текст (Александрук, 2007: 21). Текст як загальний феномен та універсалія - це також і психологічна система, результат діяльності автора, продукт який ізоморфно несе в собі певні системні закономірності (Анохін, 1975; Засєкіна, 2005). Механізми семантико- 
психологічного впливу інформації на особистість людини грунтовно доліджено Л. В. Засєкіною на основі встановлення системних закономірностей структурно-функціональної організації інтелекту особистості. Зокрема, за висновками дослідниці взаємодія суб'єкта 3 фізичним та соціальним світом відбувається через інтелектуальні процеси конструювання людиною дійсності у вигляді життєвих понять, що водночас оприявнює соціальні та особистісні взаємозв'язки у глобальному контексті людського існування (Засєкіна, 2005).

Експлікація психологічних закономірностей впливу інформації на особистість людини відбувається в процесах мовної (текстової) комунікації через алгоритми «внутрішньої мови (Л. С. Виготський) i відповідні процеси інтеріоризації. Системні закономірності тексту вступають у взаємодію з аксіологічним змістом пам'яті адресата та завдяки законам пам'яті людини викликають у нього певні психологічні ефекти, які спроможні мати як позитивний, саногенний, так і негативний, патогенний, токсичний характер впливу. Патогенні психологічні ефекти завдяки закономірностям і механізмам рефлексії, законам пам'яті спроможні тривалий час зберігати свою актуальність для суб'єкта-адресата, набувати латентного та перманентного характеру. Так само тривалі патогенні комунікативні ефекти спроможні викликати у реципієнта негативні психічні стани різного змісту та глибини. Такими станами є, наприклад, деперсоналізація, втрата ідентичності, психологічна редукція. Подібні явища не дозволяють людині виявляти себе як особистість, ефективно самопрезентуватися у взаємодії 3 іншими людьми, продуктивно дотримуватися комунікативної раціональності. За таких умов можливі різного рівня зміни свідомості людини, поява відчуття втрати власного Я, систематичних хворобливих психоемоційних станів. Це негативно позначається на якості соціальної комунікації, побутового i професійного спілкування. В легкій формі деперсоналізація, втрата ідентичності та психологічна редукція спостерігаються у психічно здорових людей, однак подальший розвиток таких станів $є$ ризикованим щодо вірогідності розвитку межевих психічних станів, психічного захворювання, формування та утвердження стійких форм девіантної поведінки.

Проблематика негативних, патогенних, інформаційно-токсичних психологічних ефектів, впливів текстів займає центральне місце в 
предметному полі інформаційної безпеки людини і суспільства (Золотар, 2018). Зокрема, «інформаційно-психологічний вплив розглядається як вплив на свідомість та підсвідомість особистості й населення 3 метою внесення змін у їхню поведінку та світогляд; його базовими методами є переконання й навіювання» (Золотар, 2018: 218). Такий вплив в умовах масової комунікації, як підкреслює О.О.З Золотар 3 посиланням на відповідну класифікацію О. В. Сидоренко, може здійснюватись через застосування механізмів $і$ закономірностей 1) маніпуляції - прихованого від опонента впливу на нього, на його систему ставлень та орієнтацій; 2) емоційне зараження - передачу свого стану і ставлення іншій людині або групі осіб; 3) навіювання - навмисного свідомого впливу на підсвідомість людини або групи осіб з метою зміни їхнього стану або відношення до питання, а також створення схильності до певних дій (Золотар, 2018: 218).

Для нашого дослідження важливо встановити, які атрибути тексту як універсалії та світоглядного феномену (Александрук, 2007: 21), лінійної послідовності знаків і матеріальної оболонки ідеальних результатів людської діяльності, спроможні здійснювати психологічний ефект на свідомість людини i яким чином це відбувається в процесі трансляції, перенесення, а за певних обставин й інкорпорації певних смислових концептів, узмістовлень від адресанта (відправника) до адресата (отримувача).

У ситуації, коли реципієнт засвоює зміст будь-якого тексту, семантико-синтаксичні властивості такого тексту як пускові аферентації процесів сприйняття та засвоєння через механізми психічного системогенезу, збуджують об'єкти пам'яті реципієнта, виводять такі об'єкти із загального депо пам'яті у його свідомість. Такі семантико-синтаксичні властивості тексту представлені в ньому конкретними лексемами та їх відношеннями. Водночас i актуалізовані текстом об'єкти пам'яті реципієнта, вербалізуючись у свідомості, також є лексемами (за внутрішньо-суб'єктним механізмом - семемами) «внутрішньої мови» (Л. С. Виготський) реципієнта. Вербалізація, лексемне оформлення об'єктів пам'яті під впливом обстановочних, текстових аферентацій відбувається на основі психологічних механізмів словесної асоціації та асоціативних законів та відповідних психологічних ефектів. Механізми словесної (семантичної) асоціації тут діють відповідно до ключового принципу 
системогенезу - вивільнення компонентів системи від надлишкових ступенів свободи (Анохін, 1975). Тобто усвідомлення і розуміння пропозицій тексту відбувається шляхом вивільнення асоиіативних зв 'язків лексем тексту та об'єктів пам'яті людини від надлишкових ступенів семантичної, значеннєвої свободи таких зв'язків. Водночас певні семантико-синтаксичні властивості тексту спроможні або перешкоджати такому процесу, гальмуючи розуміння пропозицій тексту, або форсувати сприйняття реципієнтом пропозицій раніше аніж він оцінить щонайменше ризики для своєї ціннісної та психоемоційної сфери таких пропозицій. Наведені завади стабільного системогенезу сприймання тексту реципієнтом спроможні виступати як мехінізм індоктринації або «процес активного навіювання різними засобами певних ідеологічних поглядів... Індоктринація вважається різновидом маніпуляції свідомістю, «промиванням свідомості») (Золотар, 2018: 219).

Семантико-синтаксичні властивості тексту, що спроможні бути джерелами активного навіювання, індоктринації у семантичне ціннісне поле реципієнта певних смислів, також пов'язані із закономірностями психологічних законів пам'яті. Передусім ефективність та висока вірогідність індоктринального психологічного впливу на реципієнта пов'язані із законами зв'язку пам'яті 3 емоціями, мотивацією (потребами), 3 мисленням, законами незавершеної дії і краю. Емоційність тексту, передусім трансляція текстовими одиницями базових емоцій, наприклад здивування, страху, туги або відрази, пригнічує когнітивні процеси, процеси мислення, що спрямовані насамперед на критичне усвідомлення i вичерпне розуміння пропозицій тексту. Водночас емоції посилюють увагу людини до об'єкта, на який вони спрямовані, особливо виразно та впливово тоді, коли емоція досягає рівня афекту.

Глибина та поширення ефектів від психологічних та психолінгвістичних впливів семантико-синтаксичних властивостей текстів на свідомість людини пов'язані також із дією психологічних феноменів натуралістичної омани (naturalistic fallacy - англ.) та самовпевненості (overconfidence phenomenon - англ.). Відповідно суб'єкт неусвідомлено схиляється переоцінювати правильність своїх суджень, тяжіє до швидких або зручних рішень. Отже, за умов регулярного впливу текстів із певними семантико-синтаксичними i психологічними властивостями механізми натуралістичної омани та 
самовпевненості спроможні ставати засобами «м'якої» індоктринації потрібних адресанту цінностей та переконань.

Обговорення результатів. За результатами проведеного нами аналізу в тексті можна визначати розлогий клас лексем, що є носіями ефектів активного навіювання, індоктринації вигідних авторові, адресанту смислів. Такими лексемами спроможні бути: 1) перформативні лексеми або лексеми з характеристиками іллокуції чи перлокуції (закони зв'язку пам'яті 3 емоціями та мотивацією, ефект емоційного посилення уваги); 2) лексеми, що відіграють у реченні або більш складній мовленнєвій одиниці (як компоненти певного рівня в тексті) роль семантичного системоутворюючого фактору (всі закони пам'яті); 3) лексеми, що синтаксично розміщені на початку та наприкінці тексту або лексеми вищого рівня (закон (ефект) краю); 4) лексеми, що гальмують або спотворюють критичне розуміння пропозицій тексту задіянням семантичної варіативності, логічної незавершеності, плутанини, алогічності (закон незавершеної дії або ефект Зейгарнік, порушення принципу кооперації Х.-П. Грайса); 5) лексеми, що спроможні стимулювати виникнення у реципієнта ефекту Барнума через пряме звернення до адресата, формування у нього ілюзії персональної значущості щодо тематики тексту. Такі класи лексем активного навіювання, індоктринації вигідних адресантові смислів в умовах масової комунікації виступають як засоби використання закономірностей «мовної гри» (Вітгенштайн, 1958; Остін, 1964).

Психолінгвістичні механізми індоктринації надають головному суб'єкту мовної гри - ініціатору існування тексту, можливість дистанційно, перманентно, довготривало та певною мірою приховано отримувати результати у вигляді потрібних такому суб'єкту змін у переконаннях, цінностях, установках та поведінці реципієнта завдяки ефектам та смислам, що несе із собою текст.

Висновки та перспективи. Проведене теоретичне дослідження психологічних закономірностей феномену мовної (мовленнєвої) гри надало змогу актуалізувати психологічну проблематику психогенного впливу тексту (медіа-продукту) на свідомість людини; окреслити підходи до визначення місця і ролі мовної (мовленнєвої) гри як атрибуту інформаційно-психологічної безпеки особистості в сучасних умовах; обгрунтувати семантико-психологічну детермінацію наслідків впливу інформаційних засобів, медіа на 
свідомість людини.

Психологічні та психолінгвістичні властивості конкретного тексту як феномену соціальної комунікації спроможні бути джерелами індоктринації у семантичне ціннісне поле адресата певних смислів, а також збурень у нього потрібних адресанту психоемоційних станів. Це відбувається завдяки психологічним законам незавершеної дії, зв'язку пам'яті з емоціями та мотивацією, закону краю, ефектів емоційного посилення уваги, феноменам натуралістичної омани та самовпевненості, ефекту Барнума. Структура відповідної концепції включає психологічну та семантикосинтаксичну диференціацію п’яти класів лексем відповідно до їх перформативно-критеріальних характеристик.

У перспективі вважаємо за доцільне здійснювати подальші психологічні та психолінгвістичні розвідки про роль і функціональне значення мовної (мовленнєвої) гри та явища перформативності тексту як атрибутивних складників медіа-комунікації. Перспективним прикладним завданням також вважаємо параметризацію наведених класів лексем відповідно до їх перформативно-критеріальних характеристик та можливого психогенного впливу тексту на свідомість людини.

\section{Література}

1. Агаєв, Н. А., Базарний, В. Т. Сфімова, В. В. Мараєва, В. В. Панін, В. В. Топальский, В. Л., (2014). Формування образу ворога у воєнно-політичному конфлікті. Київ: НДЦ ГП ЗС України.

2. Александрук, I. В. (2007). Теорія можливих світів: поняття завершеності/незавершеності, правдивості/неправдивості пропозиції. Лінгвістика ХХІ століття: нові дослідження і перспективи, 29-38.

3. Анохин, П. К. (1975). Очерки по физиологии функциональных систем. Москва: Медицина.

4. Витгенштейн, Л. (1999). Голубая книга. Москва: Дом интеллектуальной книги.

5. Витгенштейн, Л. (1994). Философские работы (Ч. 1.). Москва: Издательство «Гнозио».

6. Войскунский, А. Е., \& Аветисова, А. А. (2009). Традиционные и современные исследования игрового поведения. Методология и история психологии, 4(4), 82-94.

7. Выготский, Л. С. (2000). Психология. Москва: Изд-во ЭКСМО-Пресс.

8. Жарков, Я. М., Компанцева, Л. Ф., Остроухов, В. В., Петрик, В. М., Присяжнюк, М. М., Скулиш, Є. Д. (2012). Історія інформаційно-психологічного протиборства. Київ: Наук.-вид. відділ НА СБ України. 
9. Засєкіна, Л. В. (2005). Структурно-функціональна організація інтелекту. Острог: Вид-во Нац. ун-ту «Острозька академія».

10. Зірка, В. В. (2005). Мовна парадигма маніпулятивної гри в рекламі. Автореф. дис. д-ра. філол. наук. Київ.

11. Золотар, О. О. (2018). Інформаційна безпека людини: теорія і практика. Київ: ТОВ «Видавничий дім «АртЕк».

12. Кара-Мурза, С. Г. (2000). Манипуляция сознанием. Москва: Алгоритм.

13. Компанцева, Л. Ф. (2016). Соціальні комунікації для фахівців сектору безпеки та оборони. Київ: Видавець Карпенко В. М.

14. Лакофф, Д., Джонсон, М. (2004). Метафоры, которыми мы живем. Москва: Едиториал УРСС.

15. Мак-Квейл, Д. (2010). Теорія масової комунікації (Переклад О. Возьна, Г. Сташків). Львів: Літопис.

16. Навасартян, Л. Г. (2017). Языковые средства и речевые приемы манипуляции информацией в СМИ (на материале российских газет). Дис. канд. филол. наук. Саратов.

17. Найдьонова, Л. А. (2015). Медіапсихологія: основи рефлексивного підходу. Кіровоград: Імекс-Лтд.

18. Немов, Р. С. (2007). Психологический словарь. Москва: Гуманитар. изд. центр ВЛАДОС.

19. Новиков, Д. А., Чхартишвили, А. Г. (2003). Рефлексивные игры. Москва: СИНТЕГ.

20. Остин, Д. (2006). Три способа пролить чернила: Философские работы. Москва: Колопотина, Санкт-Петербург: Изд-во «Алетейя».

21. Давыдова, В. В., Запорожца, А. В. Ломова, Б. Ф. (Ред.). (1983). Психологический словарь. Москва: Науч.-исслед. ин-т общей и педагогической психологии Акад. пед. наук СССР. Педагогика.

22. Селіванова, О. О. (2008). Сучасна лінгвістика: напрями та проблеми. Полтава: Довкілля-К.

23. Смолян, Г. (2013). Рефлексивное управление - технология принятия манипулятивных решений. Труды института системного анализа $P A H, 63(2)$, $54-61$.

24. Степанов, О. М. (2006). Психологічна енциклопедія. Київ: «Академвидав».

25. Титаренко, Т. М., Кочубейник, О. М., Черемних, К. О. (2014). Психологічні практики конструювання життя в умовах постмодерної соціальності. Київ: Міленіум.

26. Філософський енциклопедичний словник (2002). Київ: Абрис.

27. Фурман, А. В., Шандрук, С. К. (2014). Сутність гри як учинення. Тернопіль: ТНЕУ.

28. Хейзинга, Й. (2011). Homo ludens. Человек играющий. СанктПетербург: Изд-во Ивана Лимбаха.

29. Reber, A. S. (1995). The Penguin dictionary of psychology (2nd ed.). Harmondsworth: Penguin. 
30. VandenBos \& Gary, R. (2015). APA dictionary of psychology (1st ed.). American Psychological Association.

\section{References}

1. Ahaiev, N. A., Bazarnyi, V. T. Yefimova, V. V., Maraieva, V. V., Panin, V. V., Topalskyi, V. L., (2014). Formuvannia obrazu voroha u voiennopolitychnomu konflikti [Formation of the image of the enemy in the military-political conflict]. Kyiv: NDTs HP ZS Ukrainy [in Ukrainian].

2. Aleksandruk, I. V. (2007). Teoriia mozhlyvykh svitiv: poniattia zavershenosti / nezavershenosti, pravdyvosti / nepravdyvosti propozytsii [Theory of possible worlds: the concept of completeness / incompleteness, truth / falsity of the proposal]. Linhvistyka XXI stolittia: novi doslidzhennia i perspektyvy - Linguistics of the XXI century: new research and perspectives, 29-38 [in Ukrainian].

3. Anokhin, P. K. (1975). Ocherki po fiziologii funktsionalnykh sistem [Essays on the physiology of functional systems]. Moskva: Meditsina [in Russian].

4. Vitgenshteyn, L. (1999). Golubaya kniga [Blue book]. Moskva: Dom intellektualnoy knigi [in Russian].

5. Vitgenshteyn, L. (1994). Filosofskie raboty [Philosophical works]. (Ch. 1.). Moskva: Izdatelstvo "Gnozio" [in Russian].

6. Voyskunskiy, A. Ye., \& Avetisova, A. A. (2009). Traditsionnye i sovremennye issledovaniya igrovogo povedeniya [Traditional and Contemporary Research on Play Behavior]. Metodologiya i istoriya psikhologii - Methodology and History of Psychology, 4 (4), 82-94 [in Russian].

7. Vygotskiy, L. S. (2000). Psikhologiya [Psychology]. Moskva: Izd-vo EKSMO-Press [in Russian].

8. Zharkov, Ya .M., Kompantseva, L. F., Ostroukhov, V. V., Petryk, V. M., Prysiazhniuk, M. M., Skulysh, Ye.D. (2012). Istoriia informatsiinopsykholohichnoho protyborstva [History of information and psychological confrontation]. Kyiv: Nauk.-vyd. viddil NA SB Ukrainy [in Ukrainian].

9. Zasiekina, L. V. (2005). Strukturno-funktsionalna orhanizatsiia intelektu [Structural and functional organization of intelligence]. Ostroh: vyd-vo Nats. un-tu "Ostrozka akademiia" [in Ukrainian].

10. Zirka, V. V. (2005). Movna paradyhma manipuliatyvnoi hry $\mathrm{v}$ reklami [Language paradigm of manipulative game in advertising]. Extended abstract of candidate's thesis. Kyiv [in Ukrainian].

11. Zolotar, O. O. (2018). Informatsiina bezpeka liudyny: teoriia i praktyka [Human information security: theory and practice]. Kyiv: TOV «Vydavnychyi dim «ArtEk» [in Ukrainian].

12. Kara-Murza, S. G. (2000). Manipulyatsiya soznaniem [Consciousness manipulation]. Moskva: Algoritm [in Russian].

13. Kompantseva, L. F. (2016). Sotsialni komunikatsii dlia fakhivtsiv sektoru bezpeky ta oborony [Social Communities for Fakhivts in the Security and Defense Sector]. Kyiv: Vydavets Karpenko V. M [in Ukrainian].

14. Lakoff, D., Dzhonson, M. (2004). Metafory, kotorymi my zhivem [The Metaphors We Live By]. Moskva: Yeditorial URSS [in Russian]. 
15. Mak-Kveil, D. (2010). Teoriia masovoi komunikatsii [Theory of mass communication]. (O. Vozna, H. Stashkiv Trans). Lviv: Litopys [in Ukrainian].

16. Navasartyan, L. G. (2017). Yazykovye sredstva i rechevye priemy manipulyatsii informatsiey v SMI (na materiale rossiyskikh gazet) [Language tools and speech techniques for manipulating information in the media (based on the material of Russian newspapers)]. Extended abstract of candidate's thesis. Saratov [in Russian].

17. Naidonova, L. A. (2015). Mediapsykholohiia: osnovy refleksyvnoho pidkhodu [Media psychology: basics of reflexive approach]. Kirovohrad: Imeks-Ltd [in Ukrainian].

18. Nemov, R. S. (2007). Psikhologicheskiy slovar [Psychological Dictionary]. Moskva: Gumanitar. izd. tsentr VLADOS [in Russian].

19. Novikov, D. A., Chkhartishvili, A. G. (2003). Refleksivnye igry [Reflexive games]. Moskva: SINTYeG [in Russian].

20. Ostin, D. (2006). Tri sposoba prolit chernila: Filosofskie raboty [Three Ways To Spill Ink: Philosophical Works]. Moskva: Kolopotina [in Russian].

21. Davydova, V. V., Zaporozhtsa, A. V., Lomova, B. F. (Eds.). (1983). Psikhologicheskiy slovar [Psychological Dictionary]. Moskva: Nauch.-issled. in-t obshchey i pedagogicheskoy psikhologii Akad. ped. nauk SSSR. Pedagogika [in Russian].

22. Selivanova, O. O. (2008). Suchasna linhvistyka: napriamy ta problem [Modern linguistics: directions and problems]. Poltava: Dovkillia-K [in Ukrainian].

23. Smolyan, G. (2013). Refleksivnoe upravlenie - tekhnologiya prinyatiya manipulyativnykh resheniy [Reflexive control is a technology for making manipulative decisions]. Trudy instituta sistemnogo analiza RAN - Proceedings of the Institute for Systems Analysis of the Russian Academy of Sciences, 63(2), 54-61 [in Russian].

24. Stepanov, O. M. (2006). Psykholohichna entsyklopediia [Psychological encyclopedia]. Kyiv: «Akademvydav» [in Ukrainian].

25. Tytarenko, T. M., Kochubeinyk, O. M., Cheremnykh, K. O. (2014). Psykholohichni praktyky konstruiuvannia zhyttia $\mathrm{v}$ umovakh postmodernoi sotsialnosti [Psychological practices of constructing life in the conditions of postmodern sociality]. Kyiv: Milenium [in Ukrainian].

26. Filosofskyi entsyklopedychnyi slovnyk [Philosophical encyclopedic dictionary]. (2002). Kyiv: Abrys [in Ukrainian].

27. Furman, A. V., Shandruk, S. K. (2014). Sutnist hry yak uchynennia [The essence of the game as an act]. Ternopil: TNEU [in Ukrainian].

28. Kheyzinga, Y. (2011). Homo ludens. Chelovek igrayushchiy [Homo ludens. The man playing]. Sankt-Peterburg : Izd-vo Ivana Limbakha [in Russian].

29. Reber, A. S. (1995). The Penguin dictionary of psychology (2nd ed.). Harmondsworth: Penguin.

30. VandenBos \& Gary, R. (2015). APA dictionary of psychology (1st ed.). American Psychological Association.

Received: 03.05.2021

Accepted: 19.05.2021 